\title{
MODIFICATIONS OF DOLOMITE-BASED SELF-COMPACTING CONCRETE PROPERTIES USING MINERAL ADDITIVES
}

\author{
Marija Jelčić Rukavina, Ivan Gabrijel, Dubravka Bjegović
}

Preliminary notes

This paper addresses fresh and hardening properties of self compacting concretes (SCC) made with dolomite filler and pozzolanic materials, fly ash and matekaolin as cement replacement in different amounts. For this study, seven mixtures were prepared with a constant water-to-powder ratio and powder content. Fresh SCC properties were assessed by means of slump flow, L-box and sieve segregation test, while hardened properties were evaluated by means of compressive strength and modulus of elasticity at ages of 2, 7, 14, 28 and 365 days. In addition, the activity of mineral additives was assessed by heat of hydration measurement. Obtained results showed that mixtures containing fly ash exhibited better performance concerning workability properties needed for SCC, while cement replacement with metakaolin enhanced the mechanical properties. Slower pozzolanic activity of fly ash reflected in slower strength development, but ultimate strength obtained at the age of 365 days was not reduced by the presence of fly ash.

Keywords: dolomite filler; fly ash; fresh properties; hardened properties; metakaolin; mineral additives; self-compacting concrete

Utjecaj mineralnih dodataka na promjenu svojstava samozbijajućeg betona s dolomitnim filerom

Prethodno priopćenje

U radu su opisana istraživanja svojstava samozbijajućih (SCC) betona spravljenih s dolomitnim filerom i materijalima koji posjeduju pucolanska svojstva, letećim pepelom i metakaolinom, kao zamjena za cement u različitim postotcima. Projektirano je sedam mješavina sa jednakim omjerom voda/prah i jednakim udjelom praškastog materijala. Ispitivanja svježih svojstava su se sastojala od ispitivanja rasprostiranja slijeganjem, ispitivanja L-kutijom i ispitivanja segregacije, a u očvrsnulom stanju je ispitana tlačna čvrstoća i modul elastičnosti za različite starosti betona od 2, 7, 14,28 i 365 dana. Kako bi se pratila aktivnost dodanih mineralnih dodataka u betonske mješavine, ispitana je i toplina hidratacije. Dobiveni rezultati pokazuju da dodatak letećeg pepela u mješavinama poboljšava svojstva obradljivosti, dok uporaba metakaolina poboljšava mehanička svojstva. Usporena pucolanska aktivnost letećeg pepela usporava razvoj tlačne čvrstoće, ali rezultati dobiveni ispitivanjem nakon godinu dana starosti pokazuju da konačna čvrstoća betona s dodatkom letećeg pepela nije manja u odnosu na referentnu mješavinu.

Ključne riječi: dolomitni filer; leteći pepeo; metakaolin; mineralni dodaci; samozbijajući beton; svojstva u očvrsnulom stanju; svojstva u svježem stanju

\section{Introduction}

Self-compacting concrete (abbreviated in the literature as SCC) is a special type of high performance concrete that fills the formwork with its own weight without the need for vibration during casting. Due to the many benefits of SSC that are reported in the literature (environmental, human, technological and economic) compared to conventional concrete, there is trend for its increased use in the structural applications for both site and precast work $[1,2]$.

In order to achieve a high flowability and a high segregation resistance between coarse aggregate and mortar required for self-compacting properties, the selection of mixture ingredients is based on high volume of fine particles, higher amounts of high-range water reducing (HRWR) admixtures and smaller maximum size of the coarse aggregate compared to conventional concrete.

High volume of fine particles in SCC is usually achieved by using mineral additives (pozzolanic and nonpozzolanic), since an increase in cement content in concrete mixture leads to a significant rise in material cost and sometimes can have negative effects on concrete properties (e.g. increased thermal stresses and shrinkage, etc.). Among non-pozzolanic materials limestone powder is most often used [3], but scarce data in the available literature show that dolomite powder, also can be satisfactorily used for the production of SCC $[4,5]$.

Fly ash $[6 \div 10]$, ground granulated blast furnace slag $[11 \div 13]$, silica fume $[7,14]$ but in the latest years also metakaolin $[5,13 \div 16]$ are reported in the literature as pozzolanic materials that are usually used in SCC production.

Pulverized fly ash is one of the most widely used additions in concrete, because of the benefits of heat reduction and pozzolanic reactivity. Recommended usage in concrete is about $15 \div 40 \%$ replacement of cement [17]. Its usage in concrete reduces the amount of superplasticizer necessary to obtain similar slump compared with the concrete containing only cement as a binder. Because of its slower cementing activity, fly ash contributes towards long-term strength of concrete [18].

Compared to fly ash which is a secondary product from industry, metakaolin, as a thermally activated aluminosilicate material, is a primary product, produced with a controlled process. Recommended usage in concrete is up to $30 \%$ replacement in cement [19]. Among many benefits that can be achieved by using metakaolin in concrete production, it is worth to highlight enhancing strength, shortening setting time and improving the durability of concrete $[19,20]$. Since the price of metakaolin is on most markets significantly higher than cement, the main reason for use of metakaolin in concrete is more technological or environmental than economical [13].

\section{Experimental work}

In this paper, fresh and hardened properties of selfcompacting concretes made with dolomite filer and mineral additives as cement replacement were investigated. For that purpose, seven self-compacting concrete mixtures were prepared. The binder for the 
control of self-compacting mixture included ordinary Portland cement (PC) and dolomite filler (D), while in six other mixtures, beside cement and dolomite, part of the cement was replaced with $5 \div 15 \%$ of metakaolin (MK) and $20 \div 40 \%$ fly ash (FA)(by weight). Fresh properties included filling, passing ability and segregation resistance of SCC, while the hardened properties included compressive strength and modulus of elasticity development up to 365 days. Additionally, to have the insight into the hydration process within the concrete mixtures, heat of hydration was measured.

\subsection{Materials and mixing method}

CEM I 42.5 R conforming HRN EN 197-1 [21] was used for all mixtures. Mineral additives used are commercially available at Croatian market. Tab. 1 summarizes properties of the PC and mineral additives used in studied mixtures, while Fig. 1 shows their particle size gradation obtained by the laser analysis with minimum sieve opening of $4,5 \mu \mathrm{m}$ for cement and $0,1 \mu \mathrm{m}$ for metakaolin, fly ash and dolomite. The fine and coarse aggregate used was dolomite with a nominal maximum size of $16 \mathrm{~mm}$ in order to avoid any blocking effect of SCC. Fig. 2 presents particle size gradation of used aggregate obtained by sieve analysis.

All mixtures were designed in accordance with CBI method developed in Sweden [22], but already satisfactorily applied on the design of SCC mixtures made with available materials in Croatia [23]. Constant powder quantity $\left(670 \mathrm{~kg} / \mathrm{m}^{3}\right)$ and constant water-to-powder ratio $(w / p=0,27)$ were selected for all mixtures, in which the powder content, $\mathrm{p}$, is defined as the sum of the cement, mineral additive and dolomite content. The concrete mixtures were designed to give slump flow of $700 \pm 50$ $\mathrm{mm}$ which was achieved by using the superplasticizer (SP) based on modified polycarboxylic ethers at amounts as indicated in Tab. 2. Tap water used for the production of all concrete mixtures was obtained from the city waterworks.

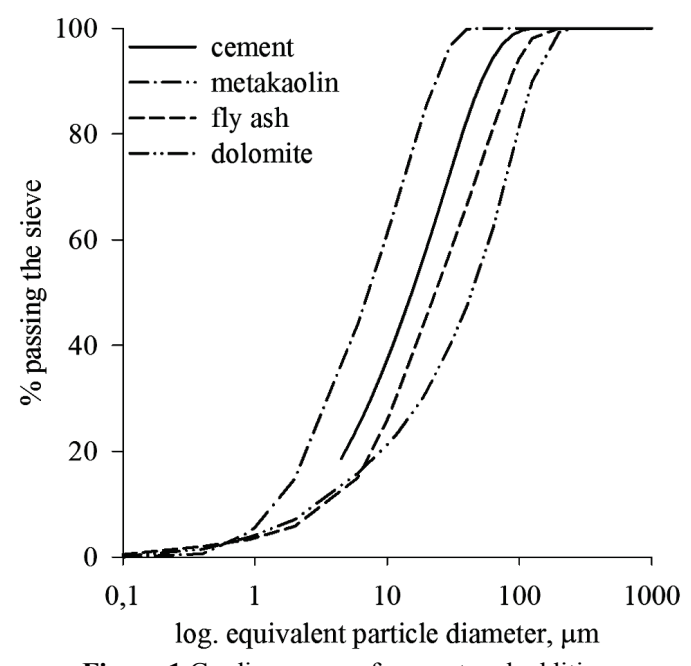

Figure 1 Grading curve of cement and additives

The batching sequence, which is presented in Fig. 3, consisted of homogenizing the fine and coarse aggregates for $5 \mathrm{~s}$ in a rotary mixer, then adding about one third of the mixing water at temperature of $20{ }^{\circ} \mathrm{C}$ into the mixer and continuing to mix for a half more minute. After cement and mineral additive were added, the mixing was resumed for another $30 \mathrm{~s}$. Then the second third of water content was added and mixing was continued for one more minute. The superplasticizer dissolved with remaining water was introduced, and the concrete was mixed for 1,5 min and then left for a 2 min rest. After the viscosity modifying agent (VMA) was added, the concrete was mixed for additional 2 min to complete the mixing sequence.

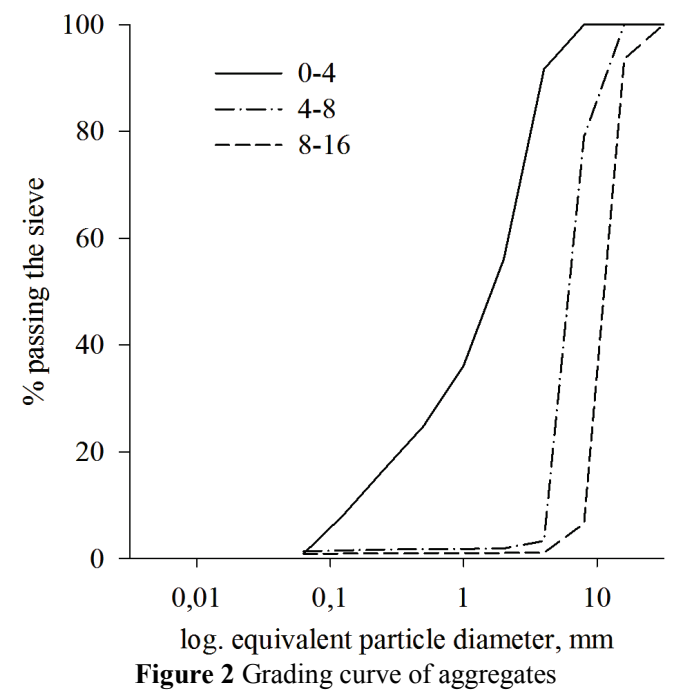

Table 1 Properties of cement and mineral additives

\begin{tabular}{|c|c|c|c|c|}
\hline Property/Component & $\mathrm{PC}$ & $\mathrm{D}$ & MK & FA \\
\hline \multicolumn{5}{|c|}{ Chemical analysis, \% } \\
\hline $\mathrm{CaO}$ & 60,23 & 30,38 & 0,55 & 4,21 \\
\hline $\mathrm{SiO}_{2}$ & 19,81 & 0,00 & 53,53 & 51,87 \\
\hline $\mathrm{Fe}_{2} \mathrm{O}_{3}$ & 2,71 & 0,18 & 1,17 & 9,22 \\
\hline $\mathrm{Al}_{2} \mathrm{O}_{3}$ & 5,38 & 0,31 & 41,18 & 24,46 \\
\hline $\mathrm{MgO}$ & 2,87 & 21,84 & 0,36 & 1,83 \\
\hline $\mathrm{Na}_{2} \mathrm{O}$ & 0,28 & 0,05 & 0,08 & 0,23 \\
\hline $\mathrm{K}_{2} \mathrm{O}$ & 0,77 & 0,02 & 0,83 & 1,14 \\
\hline $\mathrm{SO}_{3}$ & 3,07 & 0,05 & 0,08 & 0,56 \\
\hline Loss of ignition, LOI & 4,47 & 47,58 & 1,36 & 0,54 \\
\hline \multicolumn{5}{|c|}{ Physical properties } \\
\hline Density, $\mathrm{Mg} / \mathrm{m}^{3}$ & 3,05 & 2,86 & 2,68 & 2,34 \\
\hline Blaine fineness, $\mathrm{cm}^{2} / \mathrm{g}$ & 3290 & 1630 & 10260 & 3070 \\
\hline \multicolumn{5}{|c|}{ Bogue composition, $\%$} \\
\hline $\mathrm{C}_{3} \mathrm{~S}$ & 45,80 & - & - & - \\
\hline $\mathrm{C}_{2} \mathrm{~S}$ & 22,50 & - & - & - \\
\hline $\mathrm{C}_{3} \mathrm{~A}$ & 9,68 & - & - & - \\
\hline $\mathrm{C}_{4} \mathrm{AF}$ & 8,24 & - & - & - \\
\hline \multicolumn{5}{|c|}{ Mechanical properties } \\
\hline Strength $f_{\mathrm{c} 28}, \mathrm{MPa}$ & 61,18 & - & - & - \\
\hline
\end{tabular}

All concrete specimens were cast without any compaction and vibration. After casting, the specimens intended for measuring the hardened properties of SCC were kept covered in the laboratory condition for $24 \mathrm{~h}$ until demoulding to prevent evaporation of water. Thereafter, specimens were placed in a controlled moist chamber at $20 \pm 2{ }^{\circ} \mathrm{C}$ and $\mathrm{RH} \geq 95 \%$ for next 27 days. After 28 days of curing, the specimens were kept in ordinary environmental conditions $\left(\vartheta=15 \div 25^{\circ} \mathrm{C}\right.$; $\mathrm{RH}=$ $50 \div 70 \%$ ) until the age of 365 days. 


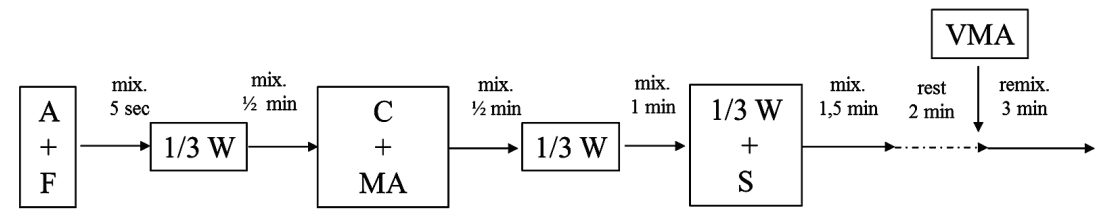

$\mathrm{A}$ - agregate; F - filler (dolomite); V - water; $\mathrm{C}$ - cement; MA - mineral additive; $\mathrm{S}$ - superplastifikator; VMA - viscosity modifying agent.

Figure 3 Mixing procedure of SCC

\subsection{Testing procedure of SCC mixtures}

Before casting, the concrete mixtures were tested in order to characterize properties needed for selfcompatibility of concrete, which included filling, passing ability and segregation resistance of SCC in accordance with set of standards for self-compacting concrete testing [24 $\div 27$ ]. As mentioned previously, concrete mixtures were designed to give slump flow of $700 \pm 50 \mathrm{~mm}$. Additionally, the slump flow time $\left(t_{500}\right)$, L-box and segregation resistance were tested for each mixture. Observation of bleeding was visually performed during the slump flow test and was not observed in any mixture. All fresh concrete tests were carried out over a period of $10 \div 15$ min after the mixing had been completed in order to reduce the effect of workability loss on the variability of test results.

Measuring of heat of hydration was performed using differential calorimeter (Tonical 7336 Heat Flow Differential Calorimeter). During the measurement, the calorimeter was situated in the chamber with controlled temperature conditions $\left(19 \pm 2{ }^{\circ} \mathrm{C}\right)$. The specimen for measuring was a cylindrical specimen, $300 \mathrm{~mm}$ high with a diameter of $150 \mathrm{~mm}$. After mixing, the concrete is cast in the steel mould without vibration and then put in the body of the device. The average time elapsed between the mixing and start of measuring was about 20 minutes. The measured values are: rate of heat release, total heat of hydration and temperature evolution in the concrete specimen, which were monitored until the age of concrete of 72 hours.

Evaluation of hardened properties comprised compressive strength and static modulus of elasticity tests at the ages of $2,7,14,28$ and 365 days.

Compressive strength testing was performed according to procedure described by HRN EN 12390-3 [28] on $150 \mathrm{~mm}$ concrete cubes. Testing of static modulus of elasticity in compression was performed according to procedure described by Croatian standard HRN U.M1.025 [29] on cylindrical specimens, $200 \mathrm{~mm}$ high with a diameter of $100 \mathrm{~mm}$, when three loading-unloading cycles between $0,5 \mathrm{MPa}$ and the third of the compressive strength, obtained previously, were performed. Modulus of elasticity corresponded to the mean value of secant modulus obtained within the last cycle.

Table 2 Mix proportions (for $1 \mathrm{~m}^{3}$ )

\begin{tabular}{|c|c|c|c|c|c|c|c|c|}
\hline \multicolumn{2}{|l|}{ Mix ID } & M1-ref & $\begin{array}{c}\text { M2 } \\
\text { (MK5) }\end{array}$ & $\begin{array}{c}\text { M3 } \\
\text { (MK10) }\end{array}$ & $\begin{array}{c}\text { M4 } \\
(\mathrm{MK} 15)\end{array}$ & $\begin{array}{c}\text { M5 } \\
\text { (FA20) }\end{array}$ & $\begin{array}{c}\text { M6 } \\
\text { (FA30) }\end{array}$ & $\begin{array}{c}\text { M7 } \\
\text { (FA40) }\end{array}$ \\
\hline \multicolumn{2}{|l|}{ Cement, kg } & 450 & 427,5 & 405 & 382,5 & 360 & 315 & 270 \\
\hline \multirow{2}{*}{ Metakaolin } & $\%$ c.w. & - & 5 & 10 & 15 & - & - & - \\
\hline & $\mathrm{kg}$ & - & 22,5 & 45 & 67,5 & - & - & - \\
\hline \multirow{2}{*}{ Fly ash } & $\%$ c.w. & - & - & - & - & 20 & 30 & 40 \\
\hline & $\mathrm{kg}$ & - & - & - & - & 90 & 135 & 180 \\
\hline \multicolumn{2}{|c|}{ Dolomite, $\mathrm{kg}$} & 220 & 220 & 220 & 220 & 220 & 220 & 220 \\
\hline \multicolumn{2}{|l|}{ Water, 1} & 180 & 180 & 180 & 180 & 180 & 180 & 180 \\
\hline \multicolumn{2}{|l|}{$w / c$} & 0,40 & 0,42 & 0,44 & 0,47 & 0,50 & 0,57 & 0,67 \\
\hline \multicolumn{2}{|c|}{ Fine aggregate, kg } & 862 & 862 & 862 & 862 & 862 & 862 & 862 \\
\hline \multicolumn{2}{|c|}{ Coarse aggregate, $\mathrm{kg}$} & 696 & 696 & 696 & 696 & 696 & 696 & 696 \\
\hline \multicolumn{2}{|l|}{$\mathrm{SP}, 1$} & 5,6 & 4,5 & 5,2 & 6,3 & 4,1 & 3,6 & 3,4 \\
\hline \multicolumn{2}{|l|}{ VMA, 1} & 0,7 & 0,7 & 0,7 & 0,7 & 0,7 & 0,7 & 0,7 \\
\hline
\end{tabular}

\section{Tests results and discussion}

\subsection{Fresh properties of SCC mixtures}

Fresh properties of the studied SCC mixtures and criteria for particular class in accordance to HRN EN 2069 [24] are presented in Tab. 3.

Filing ability was evaluated by means of slump-flow test including assessing of $t_{500}$, passing ability by L-box test and resistance to segregation was evaluated by means of sieve segregation resistance test. Comparing the obtained results with the SCC criteria given in HRN EN 206-9 [24] and EFNARC recommendations [30] for particular classes that apply for SCC, it can be seen that all studied mixtures exhibited satisfactory properties in fresh state and can be used for many structural applications.

Since the workability is controlled by particle shape, particle packing effect, particle size distribution and the smoothness of surface texture, utilisation of mineral additive with different mentioned properties lead to different workability properties of studied mixtures.

In Tab. 2, the amounts of SP used in all mixtures to obtain slump flow diameter in the range of $700 \pm 50 \mathrm{~mm}$ are presented (ranging from 0,5 to $0,9 \%$ per mass of binder). Amount of VMA was kept constant for mixtures and was $0,7 \mathrm{~kg} / \mathrm{m}^{3}$. As seen from Tab. 2, the higher addition of metakaolin increased demand for the superplasticizer, while the lower dosage of 
superplasticizer is needed for the higher fly ash content. These observations concerning mixtures with metakaolin are in line with Melo et al.[15] who observed that in SCC cement pastes and concretes, higher content of metakaolin demands higher content of superplasticizer. Contrary, coarse particle size and spherical geometry of the fly ash particles reduces the friction at the aggregate-paste interface producing a "ball-bearing effect" at the point of contact, thus partial replacement of cement by FA results in increased workability of mixtures [31].

Table 3 Fresh properties of concrete mixtures

\begin{tabular}{|c|c|c|c|c|c|c|c|c|c|}
\hline \multirow{2}{*}{ Property/Mix ID } & \multicolumn{2}{|c|}{ HRN EN 206-9 } & \multirow{2}{*}{ M1-REF } & \multirow{2}{*}{$\begin{array}{c}\text { M2 } \\
\text { (MK5) }\end{array}$} & \multirow{2}{*}{$\begin{array}{c}\text { M3 } \\
\text { (MK10) }\end{array}$} & \multirow{2}{*}{$\begin{array}{c}\text { M4 } \\
\text { (MK15) }\end{array}$} & \multirow{2}{*}{$\begin{array}{c}\text { M5 } \\
\text { (FA20) }\end{array}$} & \multirow{2}{*}{$\begin{array}{c}\text { M6 } \\
\text { (FA30) }\end{array}$} & \multirow{2}{*}{$\begin{array}{c}\text { M7 } \\
\text { (FA40) }\end{array}$} \\
\hline & Class & Criteria & & & & & & & \\
\hline \multirow{3}{*}{ Slump flow, mm } & SF1 & $550 \div 650 \mathrm{~mm}$ & \multirow{3}{*}{732} & \multirow{3}{*}{720} & \multirow{3}{*}{725} & \multirow{3}{*}{727} & \multirow{3}{*}{720} & \multirow{3}{*}{720} & \multirow{3}{*}{725} \\
\hline & SF2 & $660 \div 750 \mathrm{~mm}$ & & & & & & & \\
\hline & SF3 & $760 \div 770 \mathrm{~mm}$ & & & & & & & \\
\hline \multirow{2}{*}{ Slump flow time $\left(t_{500}\right), \mathrm{s}$} & VS1 & $<2 \mathrm{~s}$ & \multirow{2}{*}{2,08} & \multirow{2}{*}{2,35} & \multirow{2}{*}{2,19} & \multirow{2}{*}{2,10} & \multirow{2}{*}{1,66} & \multirow{2}{*}{1,47} & \multirow{2}{*}{1,40} \\
\hline & VS2 & $\geq 2$ & & & & & & & \\
\hline \multirow{2}{*}{ L-box $\left(h_{2} / h_{1}\right),-$} & PL1 & $\begin{array}{c}\geq 0,8 \\
2 \text { rebars }\end{array}$ & \multirow{2}{*}{0,94} & \multirow{2}{*}{0,93} & \multirow{2}{*}{0,82} & \multirow{2}{*}{0,82} & \multirow{2}{*}{0,84} & \multirow{2}{*}{0,87} & \multirow{2}{*}{0,92} \\
\hline & PL2 & $\begin{array}{c}\geq 0,8 \\
3 \text { rebars }\end{array}$ & & & & & & & \\
\hline \multirow{2}{*}{ Segregation resistance, $\%$} & SR1 & $\leq 20$ & \multirow{2}{*}{5} & \multirow{2}{*}{8} & \multirow{2}{*}{10} & \multirow{2}{*}{10} & 5 & 6 & 6 \\
\hline & SR2 & $\leq 15$ & & & & & 5 & 0 & 0 \\
\hline Unit weight, $\mathrm{kg}$ & & & 2499 & 2485 & 2482 & 2488 & 2462 & 2438 & 2419 \\
\hline Air content, $\%$ & & & 1,9 & 2,1 & 2,4 & 2,1 & 2,3 & 2,0 & 2,3 \\
\hline
\end{tabular}

In terms of slump flow diameter, all studied mixtures exhibited required slump flow values (Fig. 5). According to HRN EN 206-9 [24] all mixtures satisfied slump-flow SF2 class that is suitable for usual applications, e.g. walls, columns etc.

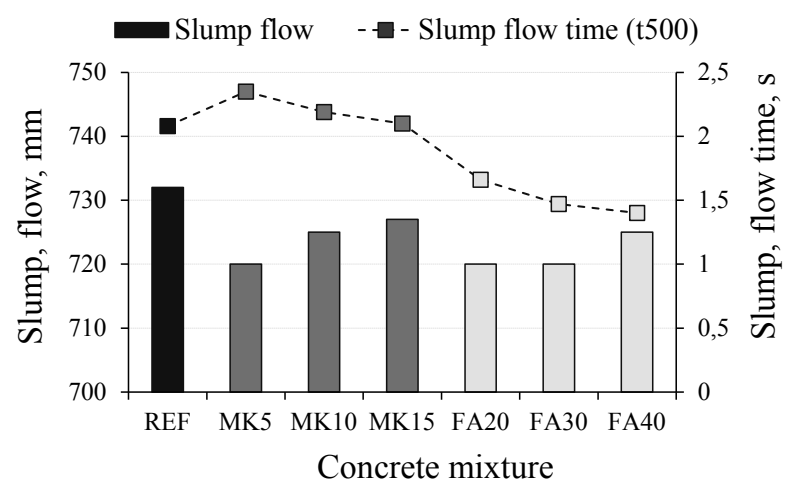

Figure 5 Slump flow and slump flow time of tested SCC mixtures

The slump flow time, $t_{500}$ values, presented in Fig. 5, exceeded $2 \mathrm{~s}$ for reference and mixtures containing metakaolin, while mixtures containing fly ash had values below $2 \mathrm{~s}$ showing lower viscosity of mixtures. The use of fly ash in mixtures appeared to be the most effective in the reduction of the slump-flow time. Thus, according to viscosity classes defined in HRN EN 206-9 [24], the former can be classified as VS2, while the latter as VS1.

The L-box blocking ratio $\left(h_{2} / h_{1}\right)$, which characterizes the passing ability, is dependent on coarse aggregate content and viscosity [32]. In order to avoid blocking effect of SCC mixtures, the maximum size of coarse aggregate was kept as $16 \mathrm{~mm}$. As per EFNARC standards [32], there is not generally a blocking risk of the mixture when the L-box blocking ratio is in the range between 0,8 and 1,0. Results in Tab. 3 and Fig. 6 show that all the studied mixtures have remained in the target range for the class PL2 as defined by HRN EN 206-9 [24]. Furthermore, it is shown that increasing the replacing level of the metakaolin L-box blocking ratio decreased, while on the other hand, increased replacing level of fly ash led to increased L-box blocking ratio.

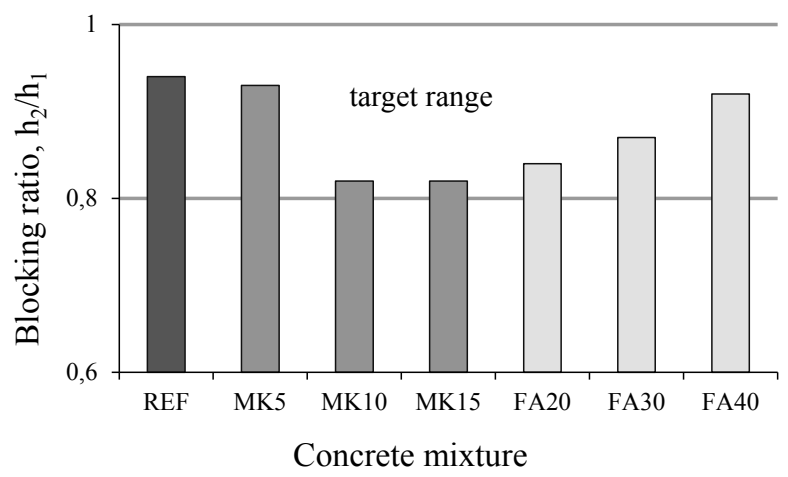

Figure 6 L-box blocking ratio of tested mixtures

In terms of segregation resistance, all mixtures exhibited satisfactory behaviour, satisfying SR2 class, i.e. segregation index was below $15 \%$. Mixtures containing metakaolin had higher segregation index $(8 \div 10 \%)$, while mixtures containing fly ash exhibited comparable (5 $\div 6 \%$ ) segregation index to the reference mixture (Tab.3).

In Tab. 3, the unit weight of the fresh mixtures is also presented. The unit weight of the control mixture was $2499 \mathrm{~kg} / \mathrm{m}^{3}$ which was the highest value. Using mineral additives as metakaolin and fly ash, the unit weight of all mixtures decreased because of their lower density $(2,68$ and $2,43 \mathrm{Mg} / \mathrm{m}^{3}$ respectively) compared to PC $(3,05$ $\mathrm{Mg} / \mathrm{m}^{3}$ ) showing that utilisation of mineral additive can decrease slightly the self-weight of SCC.

\subsection{Mechanical properties of hardened SCC}

The results of compressive strength testing of seven tested mixtures at ages 2, 7, 14, 28 and 365 days are shown in Tab. 4. The compressive strength at particular age was the average of test results of three specimens. Fig. 7 presents relative compressive strength development at same ages as in Tab. 4. Relative compressive strength presents ratio between compressive strength of particular mixture and reference mixture at the same age. 


\begin{tabular}{|c|c|c|c|c|c|c|c|}
\hline Age & M1-ref & $\begin{array}{c}\text { M2 } \\
\text { (MK5) }\end{array}$ & $\begin{array}{c}\text { M3 } \\
\text { (MK10) }\end{array}$ & $\begin{array}{c}\text { M4 } \\
\text { (MK15) }\end{array}$ & $\begin{array}{c}\text { M5 } \\
\text { (FA20) }\end{array}$ & $\begin{array}{c}\text { M6 } \\
\text { (FA30) }\end{array}$ & $\begin{array}{c}\text { M7 } \\
\text { (FA40) }\end{array}$ \\
\hline \multicolumn{8}{|c|}{ Compressive strength, $\mathrm{MPa}$} \\
\hline $2 \mathrm{~d} / \mathrm{st} . \mathrm{dev}$. & $57,3 / \pm 1,9$ & $49,2 / \pm 0,8$ & $45,1 / \pm 1,6$ & $43,9 / \pm 0,8$ & $39,0 / \pm 1,4$ & $36,8 / \pm 0,3$ & $32,1 / \pm 0,8$ \\
\hline 7d/st.dev. & $69,1 / \pm 2,0$ & $74,5 / \pm 2,5$ & $74,6 / \pm 2,1$ & $74,3 / \pm 0,6$ & $54,6 / \pm 1,1$ & $50,3 / \pm 1,3$ & $44,4 / \pm 0,2$ \\
\hline $14 \mathrm{~d} / \mathrm{st} . \mathrm{dev}$ & $74,2 / \pm 1,7$ & $78,5 / \pm 1,6$ & $83,7 / \pm 1,8$ & $82,9 / \pm 0,9$ & $59,9 / \pm 0,1$ & $56,3 / \pm 1,2$ & $49,4 / \pm 0,4$ \\
\hline $28 \mathrm{~d} /$ st.dev. & $81,1 / \pm 1,1$ & $82,3 / \pm 0,2$ & $91,6 / \pm 2,1$ & $89,6 / \pm 5,6$ & $67,1 / \pm 2,2$ & $65,0 / \pm 1,2$ & $57,5 / \pm 1,3$ \\
\hline $365 \mathrm{~d} / \mathrm{st} . \mathrm{dev}$. & $104,2 / \pm 2,4$ & $107,3 / \pm 1,2$ & $116,3 / \pm 3,1$ & $118,3 / \pm 1,8$ & $108,1 / \pm 3,1$ & $109,0 / \pm 4,8$ & $109,6 / \pm 0,8$ \\
\hline \multicolumn{8}{|c|}{ Es, GPa } \\
\hline $2 \mathrm{~d} / \mathrm{st} . \mathrm{dev}$. & $33,7 / \pm 1,5$ & $30,1 / \pm 1,9$ & $30,0 / \pm 1,0$ & $26,7 / \pm 0,8$ & $27,6 / \pm 0,9$ & $26,4 / \pm 1,3$ & $24,4 / \pm 0,3$ \\
\hline 7d / st.dev. & $39,6 / \pm 1,6$ & $40,8 / \pm 2,5$ & $41,4 / \pm 0,6$ & $40,1 / \pm 1,1$ & $35,0 / \pm 0,8$ & $32,9 / \pm 2,3$ & $30,4 / \pm 0,9$ \\
\hline $14 \mathrm{~d} /$ st.dev. & $42,4 / \pm 2,5$ & $43,0 / \pm 1,3$ & $43,7 / \pm 1,2$ & $42,7 / \pm 0,8$ & $38,7 / \pm 2,2$ & $36,9 / \pm 3,0$ & $34,1 / \pm 0,2$ \\
\hline $28 \mathrm{~d} / \mathrm{st} . \mathrm{dev}$ & $43,3 / \pm 2,1$ & $43,8 / \pm 0,7$ & $44,2 / \pm 0,7$ & $43,9 / \pm 1,2$ & $41,8 / \pm 1,5$ & $40,6 / \pm 0,7$ & $37,9 / \pm 0,4$ \\
\hline $365 \mathrm{~d} / \mathrm{st} . \mathrm{dev}$. & $51,0 / \pm 2,3$ & $46,6 / \pm 1,8$ & $47,7 / \pm 2,5$ & $47,4 / \pm 0,5$ & $47,2 / \pm 0,9$ & $46,4 / \pm 0,7$ & $45,0 / \pm 0,6$ \\
\hline
\end{tabular}

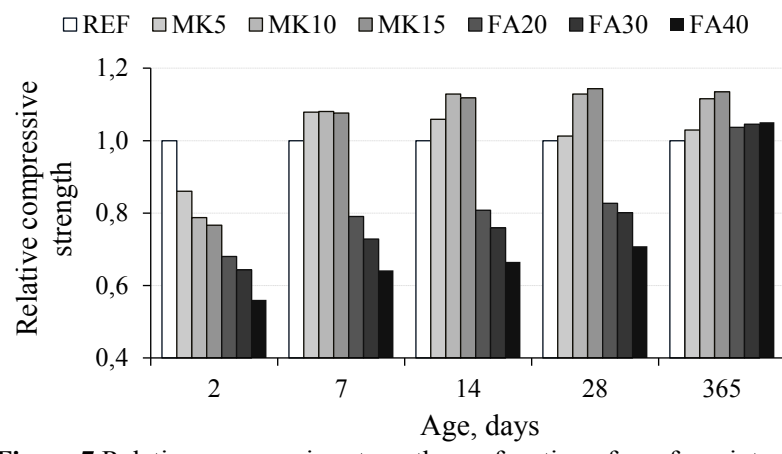

Figure 7 Relative compressive strength as a function of age for mixtures containing metakaolin and fly ash compared to reference mixture

Obtained results show that type of used mineral additive, as cement replacement in particular mixture, clearly affected the compressive strength development. From the results obtained, it is apparent that metakaolin generally produces a beneficial effect on compressive strength. Compressive strength of the mixtures modified with metakaolin developed faster than other groups of concrete (reference mixture and fly ash mixtures) after two days of curing. It can be seen from Fig. 7 that at second day of curing, replacing Portland cement with metakaolin reduces the compressive strength according to replacement level. Beyond the two days, incorporating metakaolin in the mixtures increases the relative strength where maximum contribution occurs at 14 days of curing when, compared to reference mixture more than $11 \%$ (for M3 and M4) of increase is obtained. The same trend remained through the whole studied period (i.e. 365 days). It can be seen that the highest value of compressive strength after 365 days of curing was as high as 118,3 $\mathrm{MPa}$ for mixture containing $15 \%$ of metakaolin. The higher aluminium content $(41,18 \%)$ and Blaine finesses $\left(10260 \mathrm{~cm}^{2} / \mathrm{g}\right)$ of the metakaolin possibly speeds up the hydration reaction and packs into the cement particle gaps which result in faster compressive strength development.

The obtained results are in good agreement with previous studies carried on normal-vibrated concretes made with metakaolin reported by Zhang and Malhotra [33], Wild et al. [34] and Khatib [35]. According to [34], there are three main factors that affect the positive contribution of MK to strength: 1) filling effect which is immediate; 2) the dilution effect within first 24 hours and 3 ) the pozzolanic reaction of $\mathrm{MK}$ with $\mathrm{Ca}(\mathrm{OH})_{2}$ which reaches maximum between 7 and 14 days, which is obvious in our case.

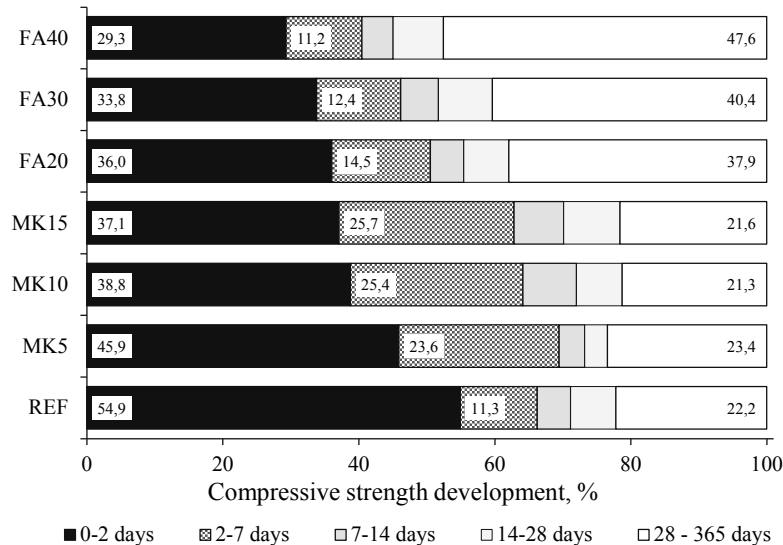

Figure 8 Compressive strength development of SCC mixtures at various ages

From Fig. 8 it can be seen that after 14 days of curing, mixtures containing metakaolin developed $70 \div 73$ $\%$ of the 365 days compressive strength, which is comparable to reference mixture $(71,1 \%)$. Mixtures containing fly ash developed from $45,1 \%$ for mixture M7 to $55,4 \%$ for mixture M5 of 365 days compressive strength after 14 days of curing. As expected, the use of FA as a cement replacement decreased the compressive strength for all replacement level till 28 days of curing (as shown in Fig. 8). At 365 days of curing, compressive strength of concrete mixtures containing fly ash is slightly higher $(108,1 ; 109$ and 109,6 MPa for mixtures M5, M6 and $\mathrm{M} 7$ respectively) compared to reference mixture (104,2 MPa). Obviously, at the early age up to 28 days of curing, pozzolanic reaction of the FA with the $\mathrm{Ca}(\mathrm{OH})_{2}$ was not sufficient to contribute to the increase in compressive strength.

As per compressive strength, influence of particular mineral additive on results of modulus of elasticity, presented in Tab. 4 and in Figs. 9 and 10, is similar for ages of concrete between 2-28 days.

At the age of two and 365 days, reference mixture has the highest value of modulus of elasticity $33,7 \mathrm{GPa}$ and $51 \mathrm{GPa}$ respectively, but from 7 to 28 day, concretes with metakaolin exhibited slightly higher values (up to $3 \%$ for mixture with $10 \%$ cement replacement with metakaolin). 


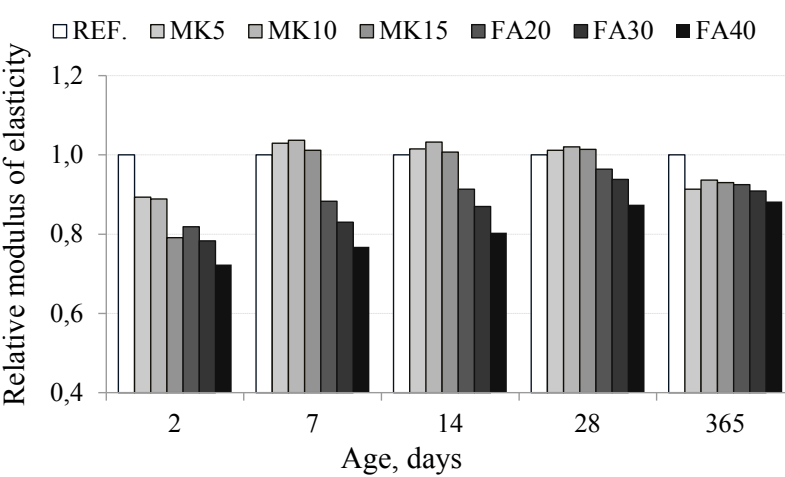

Figure 9 Relative modulus of elasticity as a function of age for mixtures containing metakaolin and fly ash compared to reference mixture

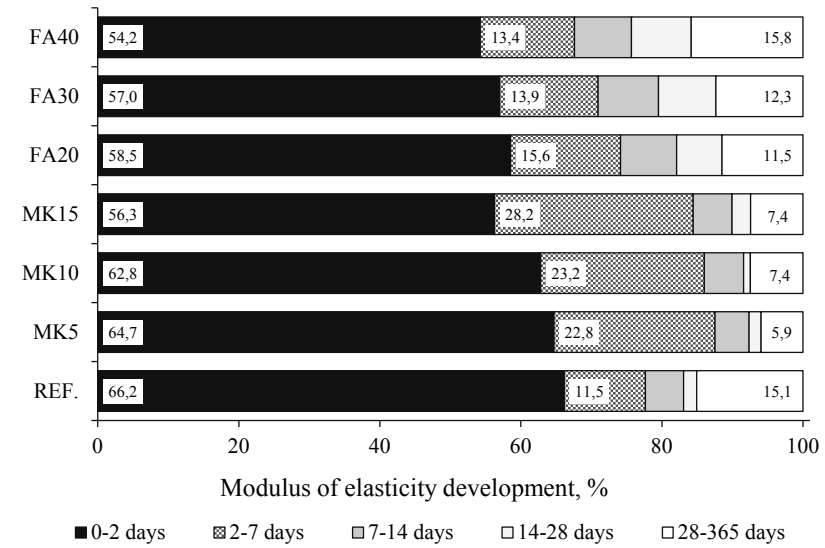

Figure 10 Modulus of elasticity development of SCC mixtures at various ages

a)

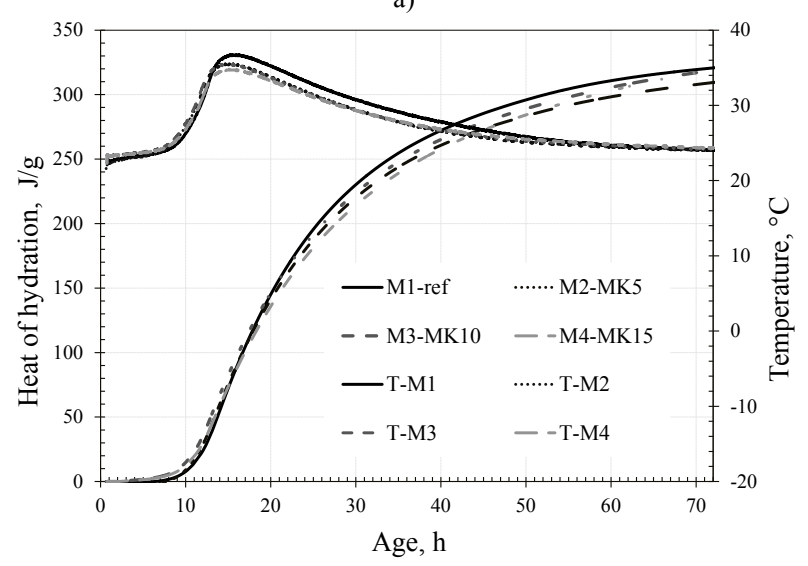

b)

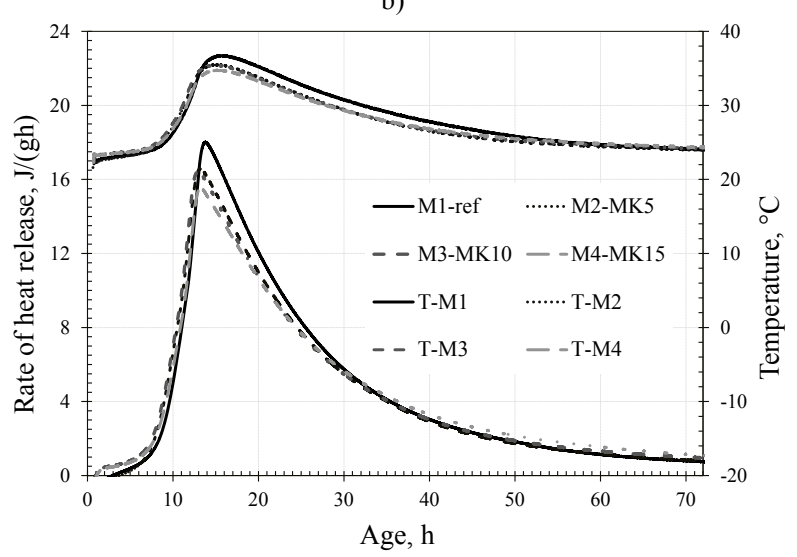

Figure 11 Evolution of temperature and a) total heat of hydration; b) rate of heat release for mixtures with metakaolin (M2, M3 and M4) compared to reference mixture (M1)

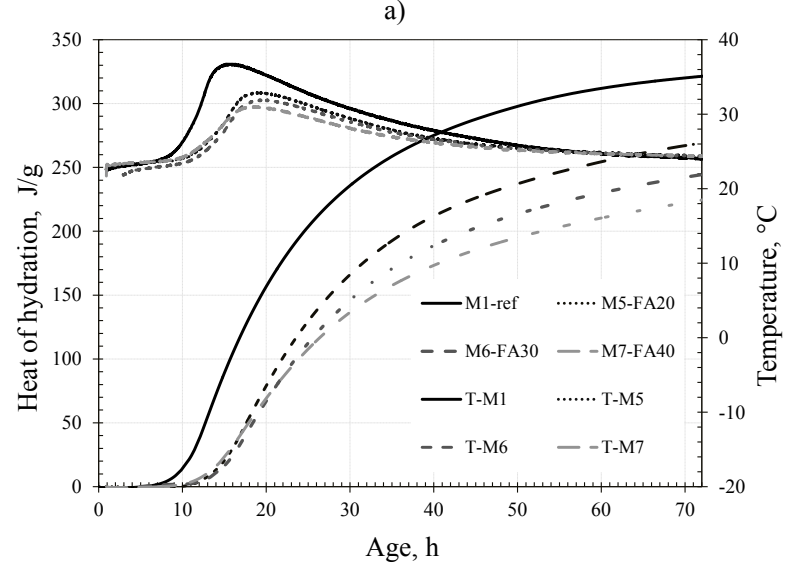

b)

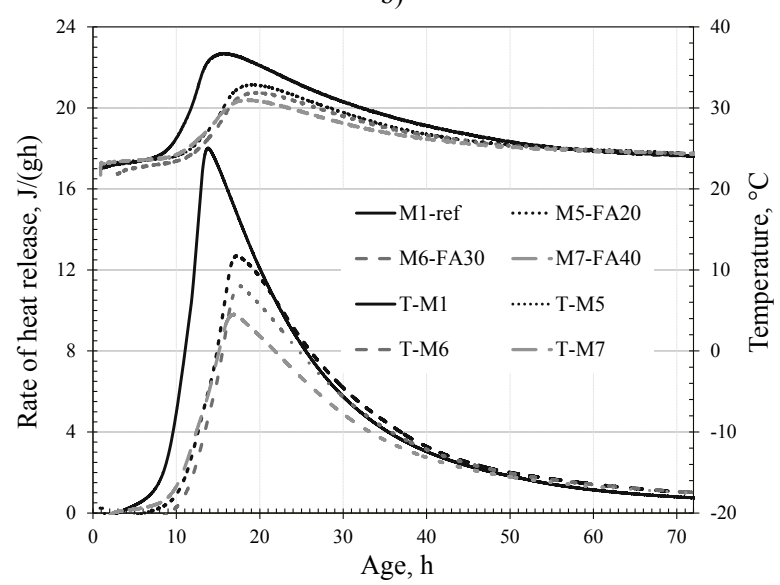

Figure 12 Evolution of temperature and a) total heat of hydration; b) rate of heat release for mixtures with fly ash (M5, M6 and M7) compared to reference mixture (M1)

Influence of cement replacement on hydration process was monitored through heat of hydration. In Figs. 11 and 12, results of heat of hydration liberated and the rate of heat liberation are presented. In each figure upper curves (designated with $\mathrm{T}$ ) present the evolution of temperature obtained in the specimens during measurement.

Replacement of Portland cement with metakaolin had a very little effect on liberated heat of hydration in the first 72 days hours of curing. This influence can be noticed in the slight shift in the peak of the rate of heat liberation curves (Fig. 11b). Replacement of Portland cement with fly ash has a very pronounced effect in the reduction of the rate of the heat liberation (Fig. 12a) and heat liberated (Fig. 12b). Larger amount of fly ash further reduced heat liberation.

Because the replacements level of CEM I in mixtures containing fly ash is much higher $(20 \div 40 \%)$ comparing to the replacement levels with metakaolin $(5 \div 15 \%)$ it is to be expected that mixtures with fly ash will show greater deviation in properties from reference mixture. Another important fact is that fly ash and metakaolin participate in the overall hydration process through different mechanisms and with opposite effects. Metakaolin practically does not change the heat evolution of concrete, but it increases strength gain development, while fly ash decreases rate of heat evolution and compressive strength gain. This effects indicate that microstructure formed with presence of metakaolin is 
obviously "better" connected, or, we could say stronger compared to pure Portland cement concrete and the reasons for this should be looked for in the properties of the hydration products formed. But, although the hydration process differs for all tested mixtures, its impact on the long term compressive strength of concrete $(365$ days) is practically negligible.

\section{Conclusions}

The following conclusions can be drawn based on the results presented in this paper:

1. Obtained results proved that dolomite powder can be used for making self-compacting concrete with acceptable fresh and hardened (compressive strength and modulus of elasticity) properties.

2. Fly ash as cement replacement ensured better fresh properties of self-compacting concrete with lower dosage of superplasticizer compared to other studied mixtures. Up to 28 days of curing, mixtures containing fly ash exhibited the lowest values of mechanical properties, but at the age of 365 compressive strength was comparable to that of reference mixture, indicating that pozzolanic reaction of the fly ash was not sufficient to increase the compressive strength at early ages. Modulus of elasticity for mixtures containing fly ash had the lowest values for all ages of concrete in accordance with replacement level

3. Metakaolin as cement replacement ensured better mechanical properties of self-compacting concrete beyond two days of curing compared to other studied mixtures. The exception were lower results of modulus of elasticity at the age of 365 days, but with variation less than $10 \%$, compared to reference mixture.

4. Improved fresh and long-term hardened mechanical properties with variation of $10 \%$ imply that through replacement of cement with mineral additives in selfcompacting concrete, the same or even better quality of concrete was achieved but with higher ecological component of sustainable concrete production.

\section{References}

[1] Report rep023: Self-Compacting Concrete - State-of-theArt Report of RILEM TC 174-SCC, (ed. Skarendahl, Å; Petersson Ö.), 2000.

[2] Craeye, B.; De Schutter, G.; Desmet, B.; Vantomme, J.; Heirman, G.; Vandewalle, L; Cizer, Ö.; Aggoun, S.; Kadri, E. H. Effect of mineral filler type on autogenous shrinkage of self-compacting concrete. // Cement and Concrete Research. 40, 6(2010), pp. 908-913.

[3] Bosiljkov, V. B. SCC mixes with poorly graded aggregate and high volume of limestone filler. // Cement and Concrete Research. 33, 9(2003), pp. 1279-1286.

[4] Barbhuiya, S. Effects of fly ash and dolomite powder on the properties of self-compacting concrete. // Construction and Building Materials. 25, 8(2011), pp. 3301-3305.

[5] Skazlić, M.; Vujica, M. Environmentally-friendly selfcompacting concrete. // Građevinar - Journal of Croatian Associatian of Civil Engineering. 64, 11(2012), pp. 905913.
[6] Bouzoubaâ, N.; Lachemi, M. Self-compacting concrete incorporating high volumes of class F fly ash. // Cement and Concrete Research. 31, 3(2001), pp. 413-420.

[7] Gesoğlu, M.; Özbay, E. Effects of mineral admixtures on fresh and hardened properties of self-compacting concretes: binary, ternary and quaternary systems. // Materials and Structures. 40, 9(2007), pp. 923-937.

[8] Khatib, J. Performance of self-compacting concrete containing fly ash. // Construction and Building Materials. 22, 9(2008), pp. 1963-1971.

[9] Liu, M. Wider application of additions in self-compacting concrete. UCL (University College London), 2009.

[10] Sukumar, B.; Nagamani, K.; Srinivasa Raghavan, R. Evaluation of strength at early ages of self-compacting concrete with high volume fly ash. // Construction and Building Materials. 22, 7(2008), pp. 1394-1401.

[11] Uysal, M.; Yilmaz, K.; Ipek, M. The effect of mineral admixtures on mechanical properties, chloride ion permeability and impermeability of self-compacting concrete. // Construction and Building Materials. 27, 1(2012), pp. 263-270.

[12] Boukendakdji，O.; Kadri， E.-H.; Kenai，S. Effects of granulated blast furnace slag and superplasticizer type on the fresh properties and compressive strength of selfcompacting concrete. // Cement and Concrete Composites. 34, 4(2012), pp. 583-590.

[13] Vejmelková, E.; Keppert, M.; Grzeszczyk, S.; Skaliński, B.; Černý, R. Properties of self-compacting concrete mixtures containing metakaolin and blast furnace slag. // Construction and Building Materials. 25, 3(2011), pp. $1325-1331$.

[14] Hassan, A.; Lachemi, M.; Hossain, K. M. Effect of metakaolin and silica fume on the durability of selfconsolidating concrete. // Cement and Concrete Composites. 34, 6(2011), pp. 801-807.

[15] Melo, K.; Carneiro, A. M. P. Effect of Metakaolin's finesses and content in self-consolidating concrete. // Construction and Building Materials. 24, 8(2010), pp. $1529-1535$

[16] Güneyisi, E.; Gesoğlu, M. Properties of self-compacting mortars with binary and ternary cementitious blends of fly ash and metakaolin. // Materials and Structures. 41, 9(2008), pp. 1519-1531

[17] Liu, M. Self-compacting concrete with different levels of pulverized fuel ash. // Construction and Building Materials. 24, 7(2010), pp. 1245-1252

[18] Khatib, J. M. Performance of self-compacting concrete containing fly ash. // Construction and Building Materials. 22, 9(2008), pp. 1963-1971

[19] Siddique, R.; Khan, M. Supplementary cementing materials, Heidelberg: Springer Berlin Heidelberg, 2011.

[20] Siddique, R.; Klaus, J. Influence of metakaolin on the properties of mortar and concrete: A review. // Applied Clay Science. 43, 3-4(2009), pp. 392-400.

[21] HRN EN 197-1:2012 Cement -- Part 1: Composition, specifications and conformity criteria for common cements (EN 197-1:2011).

[22] Billberg, P. CBI Mix Design Model for Self-Compacting concrete, PhD course, Lingby, 2002.

[23] Štirmer, N.; Pečur, I. B. Projektiranje sastava samozbijajućeg betona. // Građevinar - Journal of Croatian Associatian of Civil Engineering. 61, 4(2009), pp. 321-329.

[24] HRN EN 206-9:2010 Concrete -- Part 9: Additional Rules for Self-compacting Concrete (SCC) (EN 206-9:2010).

[25] HRN EN 12350-8:2010 Testing fresh concrete -- Part 8: Self-compacting concrete -- Slump-flow test (EN 123508:2010).

[26] HRN EN 12350-10:2010 Testing fresh concrete -- Part 10: Self-compacting concrete -- L-box test (EN 1235010:2010) 
[27] HRN EN 12350-11:2010 Testing fresh concrete -- Part 11: Self-compacting concrete -- Sieve segregation test (EN 12350-11:2010).

[28] HRN EN 12390-3:2009/Ispr.1:2012 Testing hardened concrete -- Part 3: Compressive strength of test specimens (EN 12390-3:2009/AC:2011).

[29] HRN U.M1.025: 1982 Method for testing modulus of elasticity of concrete.

[30] EFNARC, Specifications and guidelines for selfcompacting concrete. 2002.

[31] Wei, S.; Handong, Y.; Binggen, Z. Analysis of mechanism on water-reducing effect of fine ground slag, high-calcium fly ash, and low-calcium fly ash. // Cement and Concrete Research, 33, 8(2003), pp. 1119-1125.

[32] EFNARC, The European Guidelines for Self-Compacting Concrete; specification, production and use. 2005.

[33] Zhang, M. H.; Malhotra, V. M. Characteristics of a thermally activated alumino-silicate pozzolanic material and its use in concrete. // Cement and Concrete Research 25, 8(1995), pp. 1713-1725.

[34] Wild, S.; Khatib, J. M.; Jones, A. Relative strength, pozzolanic activity and cement hydration in superplasticised metakaolin concrete. // Cement and Concrete Research. 26, 10(1996), pp. 1537-1544.

[35] Khatib, J. M. Metakaolin concrete at a low water to binder ratio. // Construction and Building Materials. 22, 8(2008), pp. 1691-1700.

\section{Authors' addresses}

dr. sc. Marija Jelčić Rukavina, dipl. ing. grad.

Sveučilište u Zagrebu

Građevinski fakultet

Kačićeva 26, 10000 Zagreb, Croatia

doc. dr. sc. Ivan Gabrijel, dipl. ing. grad.

Sveučilište u Zagrebu

Građevinski fakultet

Zavod za materijale

Kačićeva 26, 10000 Zagreb, Croatia

prof. dr. sc. Dubravka Bjegović, dipl. ing. grad.

Sveučilište u Zagrebu

Građevinski fakultet

Zavod za materijale

Kačićeva 26, 10000 Zagreb, Croatia 